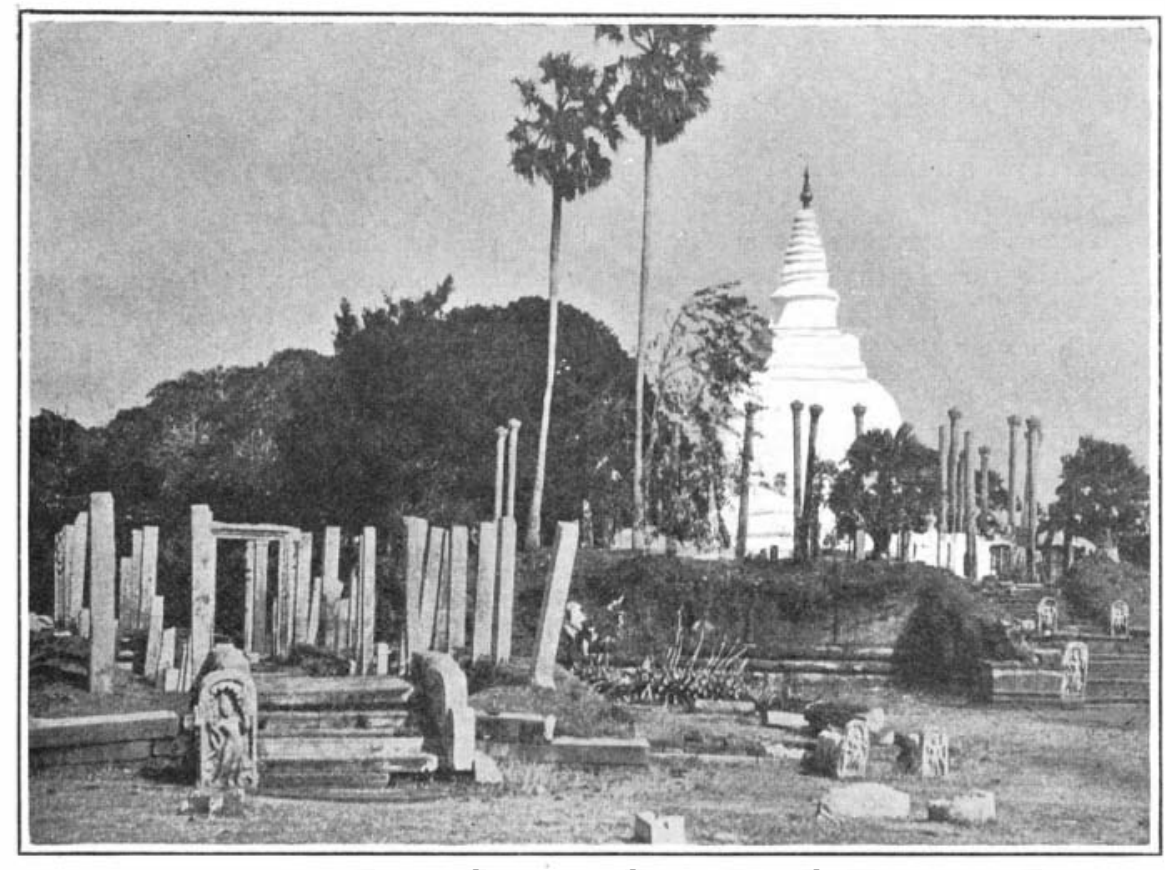

Thuparama Dagaba, at Anuradhapura said to be the oldest structure either in Ceylon or India

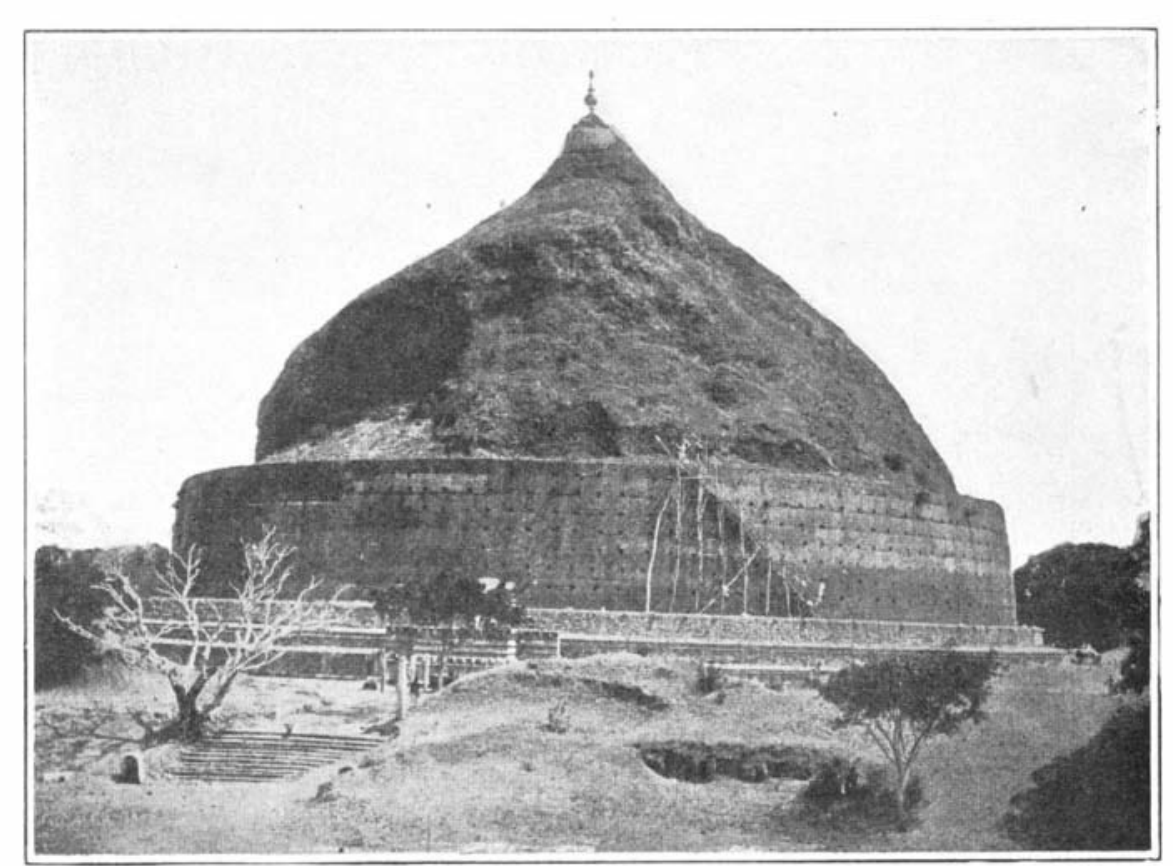

The Raunweli Dagaba, Anuradhapura; 270 feet high, 100 feet in circumference, showing elephant platform

\title{
The Ancient Capitals of Lanka
}

\section{Wonderful Ruins in Ceylon That Antedate the Christian Era}

\section{By Carl Stearns Clancy}

LoNG forgotten, still popularly unknown, and until recently half covered by the corrosive accumulations of ages and hidden by dense jungle growths, the ancient capitals of Lanka, like the ruins of the Incas in Peru, the relice of the Mayas in Guatamala, and the remains of the Aztecs in Mexico, now afford a wonderland of interest for the archæological investigator and the tourist alike.

Scores of bell-shaped relic houses, ranging up to 400 feet in height and 1,500 feet in circumference, form the gigantic ruins that now make up the principal monuments. to the magnificent civilization which thrived in Lanka (Ceylon) coevally with that of Rome, its unknown rival in luxury and architectural grandeur.

The cities were two in number, Anuradhapura, the ancient Sinhalese capital, from about 1000 B. C. to 500 A. D., and Polonarawa, the mediæval capital, which bloomed in the twelfth century.

\section{ANURADHAPURA.}

The grandeur of the mighty capital Anuradhapura with its uncounted millions of people can be guessed from the fact that the king's pleasure garden in the middle of the city was twenty square miles in extent. After his conversion to Buddhism, the reigning monarch of Lanka, King Tissa, donated these gardens for religious uses. The ruins of the temples and dagabas erected here as expressions of religious favor resulting. from the sudden subsequent conversion of the whole Sinhalese nation to Buddhism in the third century B. C. and multiplied during the zealous popular worship of this creed in the centuries that followed, now form the majority of the monuments that not only bear record to the vastness and splendor of that age, but are nowtwo thousand years later-taking their places among the wonders of the world.

Starting from the center of the modern native town numbering scarce 50,000 souls, to make a systematic tour of the ruins, one comes at first to the forest of monoliths remaining from the original 1,600 granite columns upon which rested the remarkable Brazen Palace. As this edifice, built by King Dutthagamini about 200 B. C. for his favorite community of Buddhist monks, is typical of all the palaces of that day, this brief quotation from an historical description of it, written about 500 A. D. by Buddhist monks and since preserved in their monasteries, is interesting.

"This palace was 100 cubits square-length, breadth and height all being the same. In it there were nine stories, each with 100 apartments. All these apartments were highly finished in silver; all the cornices thereof were embellished in gems. The flower ornaments thereof were also set with gems, and the tinkling festoons were of gold. In the center of the great hall of the palace was an ivory throne, on one side of which was a sun in gold, on another the moon in silver, on a third the stars in pearls," ending with "the building was covered with brazen tiles, hence its name, the Brazen Palace."

Needless to say there was not much left to a building of such intrinsic value after the series of invaders finshed with it some fourteen conturies later.

One comes next to the Ruanweli Dagaba, the laying of whose foundation is described in the opening paragraph of this article. A dagaba, or relic house, was a huge bell-shaped mound of solid bricks built both as a monument for and to protect for all time a tiny sacred relic hidden in the center of its base. Time and frequent attacks of enemies have obliterated its original outline, but there is more than sufficient structure now remaining to verify the ancient account of its erection. When the pediment was complete and the relic chamber and receptacle constructed, the relic was entombed with a most elaborate ceremony participated in by the whole

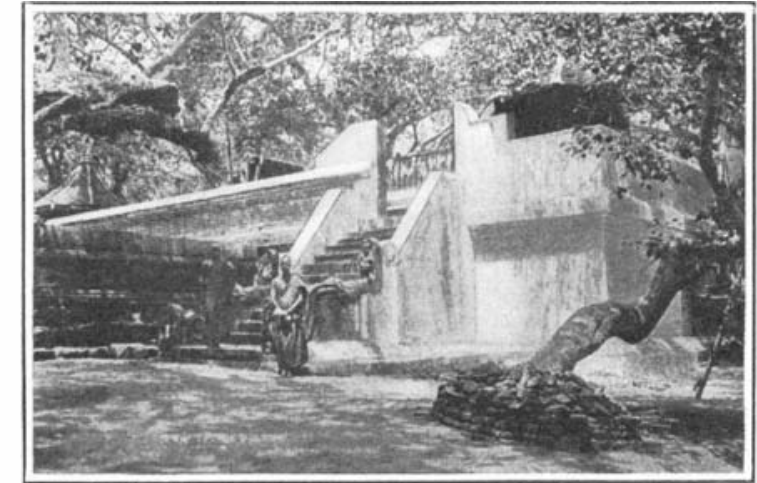

Sacred Bo-Tree, transplanted here in 288 B. C.

populace. The relic was usually a footprint of Buddha or one of his bones, but in this case it was an exquisitely beautiful model of the "Sacred Bo-tree," made of precious metals.

The work of excavating and restoring this dagaba is going on slowly, but the race that could make these great shrines what they once were has vanished. A few pious pilgrims worship here, but from all visible evidences the Buddhist religion as well as its shrines seem here to be in a hopeless ruin.

MOST ANCIENT STRUCTURE IN INDIA OR CEYLON.

The "Thuparama" Dagaba near by, the present shrine of the Collar-bone Relic, is the only dagaba in good repair and actively used. Built by King Tissa in 306 B. C., it antedates any existing structure in Ceylon or India, and is still, though much smaller than the others, a remarkable monument to the skill of its builder. Originally 176 ornamental pillars of graded heights surrounded the Thuparama; of these but 31 now remain standing.

Continuing through the park-like grounds, pastured like an English estate with sheep and goats, and broken everywhere with half-buried ruins, one visits in succession the Abhayagiriya Dagaba, the greatest of all- 405 feet high, with a dome 360 feet in diameter, and a base covering eight acres; the Jetawanarama Dagaba, not much smaller; the king's palace with its beautiful "Moonstone" entrance and decorative Guard Stones by the side; marble bath tanks equaling Rome's in luxury elephant houses and great tanks where the state elephants were wont to take their morning plunge, and where their wild descendants still come to bathe; the curious Isurminia Temple dug out of a mammoth boulder on the edge of an artificial lake; and finally the sacred Bo-tree itself.

\section{OLDEST TREE IN THE WORLD.}

Transplanted here in 288 B. C., it is said to be the oldest cultivated tree in the world. Originally a branch of the fig tree under which Buddha had been accustomed to sit and meditate, it has flourished here for twenty-one centuries. Its venerale trunk is now nearly dead, but its offspring overshadow the once beautiful court of its inclosure. Still in daily use as a shrine, the tree is becoming more important as a side show for tourists.

POLONARAWA, THE MEDIAEVAL CAPITAL.

Long before one reaches the Rest-house at Polonarawa, on the banks of a charming artificial lake forty miles to the southeast of Anuradhapura, several of the remains of its old and splendid civilization appear by the roadside. The ruins of Polonarawa are found to be not inferior in boldness of conception and richness of design to any of the medieval world to which they were contemporary, lying just as they were smitten by the fury of the ancient Tamil conquerors, but gently buried by Nature and the hand of time. Although a British Archæological Commission is at work here, excavating and restoring the grandest of ruins, trees still take root on walls and roofs and rend them asunder; rank forest vegetation covers ornamental stone carvings and sculptured figures; and elephants yet come to drink at the marble bathing pools. Temples, monasteries, dagabas rivaling the Pyramids in magnitude, and bits of one of the three rectangular walls (four miles wide by thirty miles long) that inclosed the millioned city, hold one spell-bound for hours.

The most interesting of all relics to be discovered here, however, was the temple called the "Gal Wihare," and the three giant figures at its entrance. Still part of the ledge from which they were hewn, here sits a figure of Buddha 15 feet high; next comes an erect statue 23 feet tall-it is "Ananda," Buddha's favorite disciple; then follows a recumbent staute of Buddha himself-it is only 46 feet long; Buddha was supposed to have been that size when he finally and permanently died. So clever was the work of the sculptor that the mammoth head sinks into the embroidered bolster very naturally and the graceful folds of his robe suggest nothing but calm repose. That modern devotees make pilgrimages here occasionally is shown by the remains of their flower offerings and incense candles on th? crude altar. And why should a visitor make merry: As an East Indian proverb says: "Your gods and my gods-do you or I know which is the stronger?"

The distinct feature of the Polunarawan buildings is the Hindoo character of their exterior, and this curiosity has not been explained. Shown clearly, however is the fact that this medirval capital abounded in thea- 


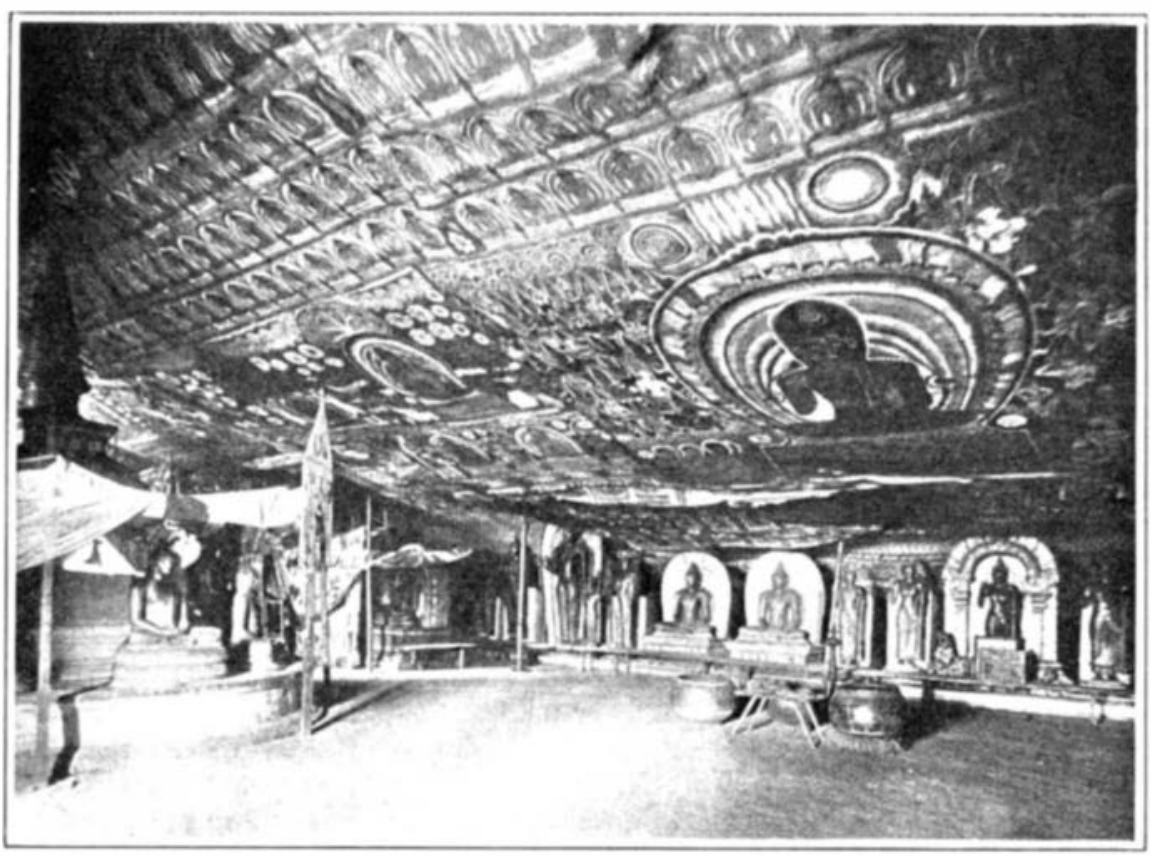

Ancient frescoes and images in the rock temple of Dambulla, dating back to 343 B. C.

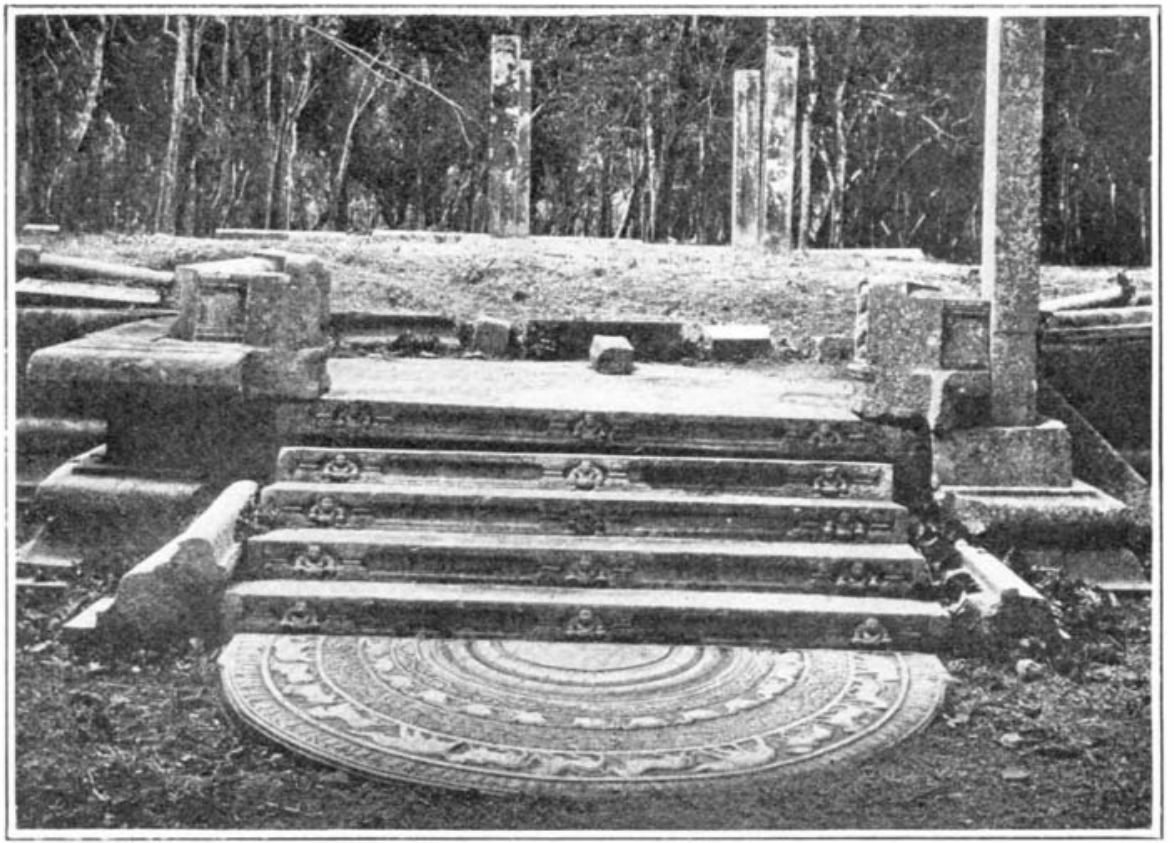

Moonstone steps in the ruined city of Anuradhapura. At entrance to the Queen's palace ters, bathing halls, gardens, fountains, public buildings that shone with roofs, doors, and windows of gold; and palaces whose splendor has never been excelled; and that it was even richer than Anuradhapura is apparent. To-day troops of huge gray monkeys, almost man size, with black faces and long black tails, leap to and fro among the trees, and excepting for the comfortable Rest-house, the jungle reigns supreme.

THE ROCK OF SIGIRI.

About the year $475 \mathrm{~A}$. D. a fiendish Sinhalese prince named Kasyapa, who had killed his father to obtain the throne, and rendered himself more unpopular by other crimes, dared no longer to live openly at Anuradhapura -then the capital-for fear of his brother's revenge. He therefore retired to the rock of Sigiri, in the center of a vast jungle, and strongly fortified it. The perpendicular sides of the rock, over 400 feet high, made climbing impossible, but the clever Kasyapa constructed a balconied stiarway gradually winding around it from base to summit. Upon the four acres of the top he built a splendid palace and administration buildings, and lived in great luxury until his Buddhist conscience began to trouble him. Later his brother's overwhelming army, recruited in India, cut his own to pieces and frightened him into suicide; whereupon his brother wrecked the fortress and returned to the north.

Several long flights of stone steps remain to lead up the terraced slopes to the foot of the cliffs, where the rock foundations of temples and houses, and huge bath tanks cut into the top of great boulders are clearly to be seen. From here one mounts the restored stairways of stone and iron to the foot of: the original inclined walk, part of which yet remains. Now a wonderful view opens out over the lake-like mist settled upon the jungle for miles around, with the craggy mountain protruding like islands in the distance.

F'orty-five feet above the center of the stairway is a pocket or shallow cave in the rock, which formed the ancient Guard Room or "look-out" for the fortress. The remarkable frescoes that still adorn its rocky wall are well worth the shaky climb up the wire and bambo ladder that hangs perilously on stays driven into the face of the cliff. Having crawled slowly up the ladder, swinging clear out beyond the jutting rock over a sheer 300-foot drop and tested his nerves to the limit, one finds several frescoes 1,430 years old-ladies with com plexions bright and fresh in spite of their exposure to the monsoons of nearly fifteen centuries.

The 9-foot wall that was built on the outside edge of the ascending gallery has an inner surface as polished and almost as hard as marble, yet it was only coated with chunan, a kind of cement that has remained $s$ well preserved that graft seems to have been unknown in ancient days. This overhanging balcony leads on and up around to the terraced north side of the rock where half the foundations of ancient buildings still remain the absent half having been supported by more temporary sub-structure. Then a long iron stairway, recently built by the Archæological Commissioners mounts to wide ledge, once the site of a temple, where the archæoogical coolies will soon be at work.

Now the royal grand staircase, partly restored, lead up in terraced flights between two collosal lion's paw and forelegs, masoned of huge bricks and mortar. A the lion's chest the original steps end, and zig-zaging iron stairs lead directly to a second ledge. From here the footholds are the original foundation drillings for the great buildings of the top, the danger of slipping being guarded by an iron hand rail.

Arriving breathless at the top, one finds four acres of what at first glance seem the half-sister to a brick yard. Exploration, however, reveals four great bath tanks cut out of the solid rock, now full of rain water; a large couch-the king's - carved out of the rock of which it

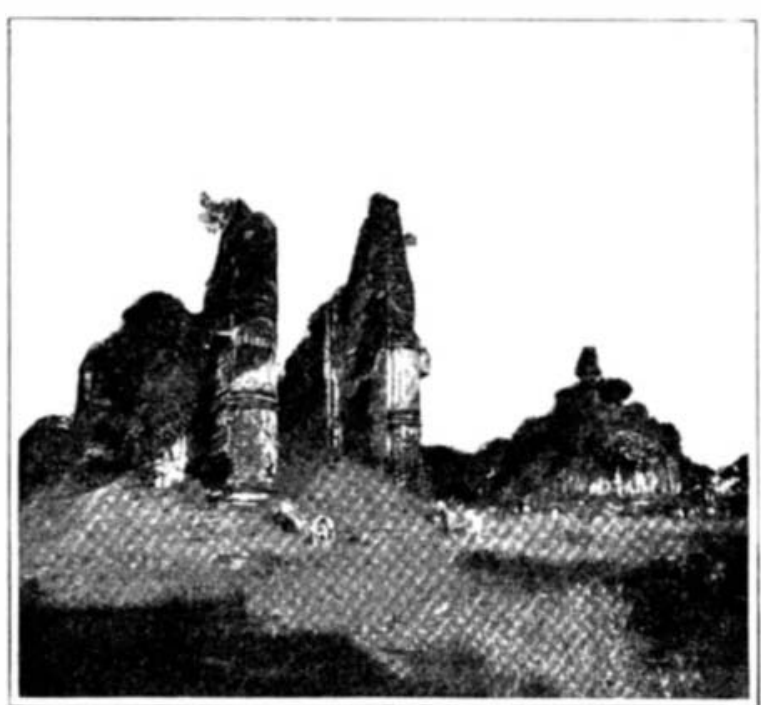

The Jetwanarama Temple and the Thuparama Dagaba at Polonarawa

is still a part, a flight of stairs in quartz, court-yards, passages, and many other evidences of royal dominion. The view from the top is magnificent, and in itsel enough to attract the crowds of people from all over the world who are expected to visit here as soon as the wonders of romantic Sigiri and the buried cities of Ceylon become more generally known.

\section{How to Recognize Good Table Poultry}

THE following statement of the methods by which good table poultry can be recognized by the purchaser is made in bulletin 467 of the Department of Agriculture. "In a freshly killed bird the feet feel moist, soft, and limber, and if it was dressed with the head on, the eye look bright and full. As it becomes stale the eyes shrink and the feet dry and harden; when too stale, $i . e$. , when decomposition is well under way, the body turns dark and greenish or becomes slimy. The flesh should be neithe fiabby nor stiff, but should give evenly and gently when pressed by the finger. It is very difficult to distinguish between good cold-storage and freshly killed poultry.

"One of the commonest ways of testing the age of dressed poultry is to take the end of the breastbone farthest from the head between thumb and finger and attempt to bend it to one side. In a very young bird, say a 'broiler' chicken or a green goose, it will be easily bent, like the cartilage in the human ear; in a bird year or so old it will be brittle, and in an old bird, tough, and hard to bend or break. Unfortunately there are sometimes tricky dealers who break the end of the breastbone before showing the bird, and thus render the test worthless. If the feet are left on the carcass, they furnish a mark of age. In a young bird they are soft and smooth, becoming hard and rough as the bird grows older. The claws are short and sharp in a young bird growing longer and blunter with age and use. Spurs generally occur on male chickens. On male broilers and tender roasting chickens they are small; on older higher-flavored ones they are prominent but flexible on cocks they are long and attached to the bones of the egs; on capons they seldom develop until the second year of age.

"Turkeys up to a year old are said to have black feet, which grow pink up to three years old and then gradually turn gray and dull.

"The age of pigeons can sometimes be told by the color of the breast, which becomes more and more purplish as the bird grows older. Red feet are also said to be a sign of age in a pigeon.

In ducks and geese the flexibility of the windpipe is a mark of youth. It can be easily squeezed and moved when the bird is young, but later grows rigid and fixed. If the tips of the quills at the end of the wing are sharply pointed the bird is probably young; the blunter they are, the older the bird.

"When caponizing has been properly done, the head is small for the size of the body, the comb and wattles are pale and withered, the body plumper, rounder, and larger than in an ordinary fowl, and the spur abortive. If the operation was incomplete, the head will be like that of an ordinary bird and the body less rounded. Such birds, known technically as 'slip capons,' are much inferior to true capons."

\section{Cable Telegraphy}

A NEW invention, devised by Mr. J. B. Dixon, has been in practical operation on certain of the Atlantic cables, and is reported to have given remarkable results, the speed of operation in the commercial handling of cable messages have been increased upwards of 125 per cent, while in tests far greater speeds have been attained. The gain in speed is due to the use of selenium cells to amplify the signals received, and to the use of means for obtaining, from one or more sources of illumination, a very large number of light beams, concentrated coincidently upon selenium cells, and deflected by a line galvanometer across the surface of the cells, the effect being that a very intense illumination of the cells is obtained. It is found that the practicable speed of operation increases as the intensity of illumination increases. The selenium cells operate a siphon recorde or a relay. There being no physical connection between the recorder or relay and the line galvanometer, the inertia and frictional losses present in the older magnifying and recording apparatus are largely eliminated, the more so as in the new system the amplitude of vibration of the galvanometer coil is, in general, much less than i the case of the older apparatus. It is stated that $\mathrm{Mr}$. Dixon employed 45 separate light beams, all derived from one 400 candle-power tungsten lamp, and all concentrated on a thin galvanometer mirror 5 inches long and $3 / 8$ inch wide. These light beams were reflected from the galvanometer mirror, in ome case, a distance of 7 fee 6 inches, and were then re-reflected a further distance of 7 feet 6 inches to the selenium cells, the light beams being concentrated coincidently upon the cells. With this apparatus, working over one of the trans-Atlantic cables, the normal rate of operation of which is less than two hundred letters per minute, a speed of 450 letters per minute and higher was obtained in the regular com mercial handling of business, and still higher speeds have been obtained on tests, with signals fully readable as to size and character.-Journal of the Royal Society of Arts. 


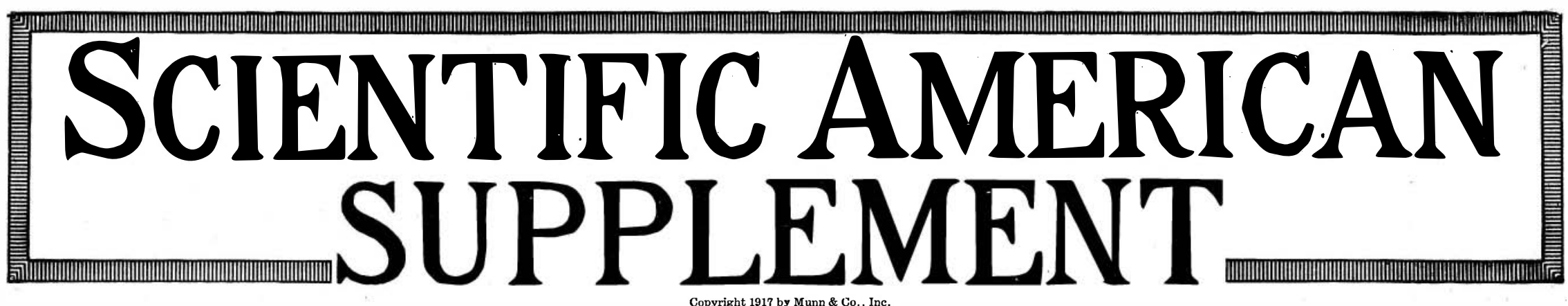

\begin{tabular}{lll}
\hline \hline NOLUME LXXXII] & $\star$ NEW YORK, MARGH 10, 1917 $\star$ MUMBER 2149 & {$\left[\begin{array}{l}10 \text { CENTS A COPY } \\
\$ 5.00 \text { A YEAR }\end{array}\right.$} \\
\hline \hline
\end{tabular}

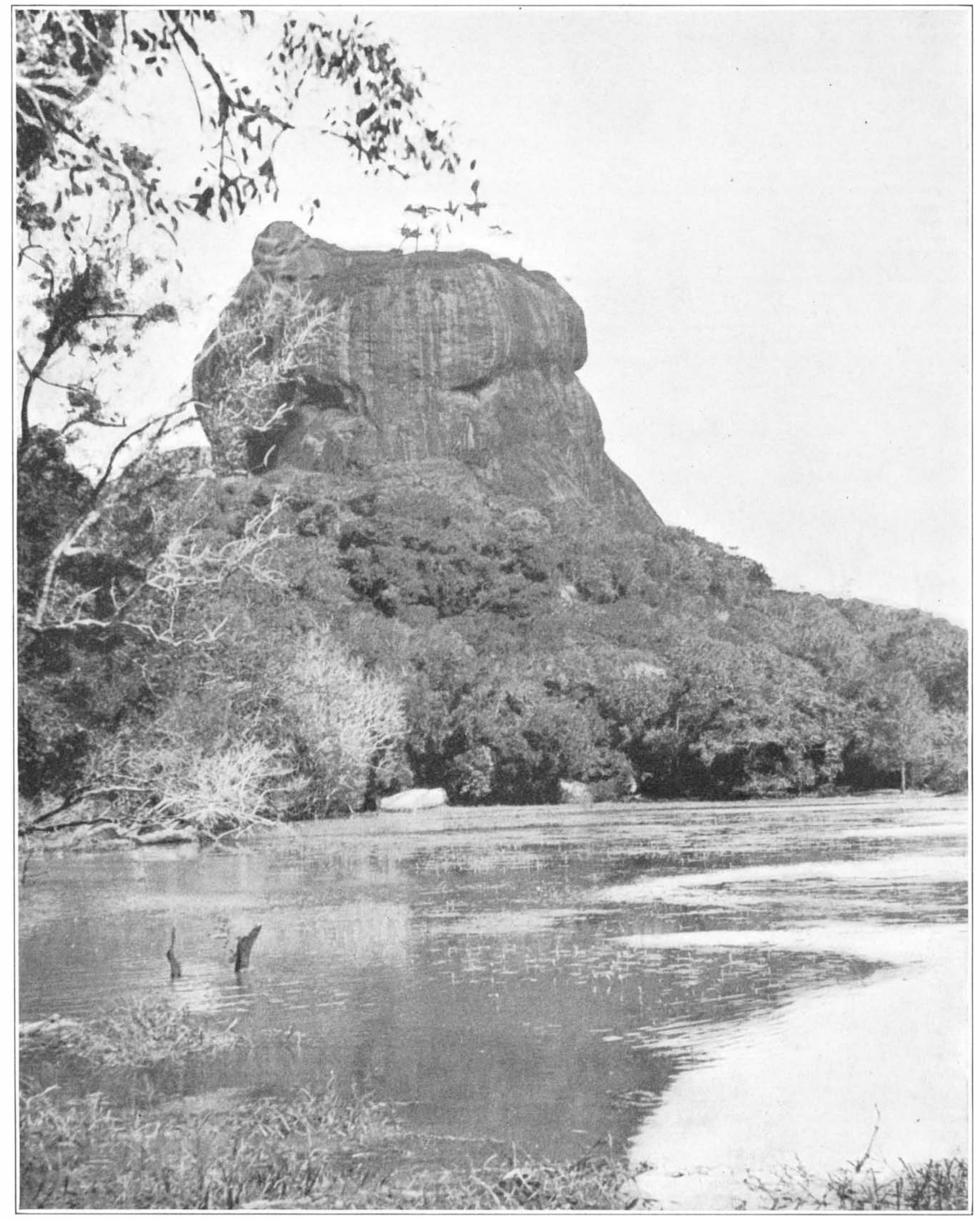

The Rock of Sigiri. The ancient capital of Ceylon was located on the four acres on the top of this rock, and a spiral roadway led to its top THE ANCIENT CAPITALS OF LANKA-[See page 152] 